\title{
The Effect of Local Government Characteristics on Performance of Local Government Administration
}

\author{
Fikri Rizki Utama*, Einde Evana**, Rindu Rika Gamayuni** \\ *Accounting Department - Institute of Economic Science of Al-Madani, Jalan Kavling Raya Pramuka Rajabasa, Bandar Lampung, 35144, Indonesia \\ **Accounting Department - University of Lampung, Jl. Prof. Dr. Sumantri Brojonegoro No. 1, Bandar Lampung, 35145, Indonesia
}

\begin{tabular}{|c|c|}
\hline ARTICLE INFO & A B S T R A C T \\
\hline $\begin{array}{l}\text { Keywords: } \\
\text { Performance of local government } \\
\text { administration, } \\
\text { level of regional wealth, } \\
\text { dependency level to the central } \\
\text { government, } \\
\text { capital expenditure contribution, } \\
\text { legislature size }\end{array}$ & $\begin{array}{l}\text { This study aimed to obtain empirical evidence of the level of regional } \\
\text { wealth, the level of dependence to the central government, capital } \\
\text { expenditure contribution and legislature size on the performance of local } \\
\text { government administration. This research used a purposive sampling } \\
\text { method. The study sample consisted of } 293 \text { LKPD provinces, districts, } \\
\text { municipalities in Indonesia in } 2015 \text { which have been audited by the } \\
\text { Supreme Audit Board. The result of the research shown that the variables } \\
\text { of legislative size had a positive and significant effect on the performance } \\
\text { of local government administration while the level of regional wealth, } \\
\text { dependency level to the central government and capital expenditure } \\
\text { contribution had no significant effect on the performance of the local } \\
\text { government. }\end{array}$ \\
\hline
\end{tabular}
ukuran legislatif.

\section{SARI PATI}

Penelitian ini bertujuan untuk mendapatkan bukti secara empiris mengenai tingkat kekayaan daerah, tingkat ketergantungan dengan pusat, kontribusi belanja modal, dan ukuran legislatif terhadap kinerja penyelenggaraan pemerintah daerah. Penelitian ini menggunakan metode purposive sampling. Sampel penelitian terdiri dari 293 LKPD provinsi, kabupaten, kota tahun 2015 di Indonesia yang telah diaudit oleh Badan Pemeriksa Keuangan. Hasil penelitian menunjukkan bahwa variabel ukuran legislatif berpengaruh positif dan signifikan terhadap kinerja penyelenggaraan pemerintah daerah sedangkan tingkat kekayaan daerah, tingkat ketergantungan dengan pusat dan kontribusi belanja modal tidak berpengaruh signifikan terhadap kinerja penyelenggaraan pemerintah daerah. 


\section{INTRODUCTION}

To realize good governance, the government keeps making efforts to improve transparency and accountability of state financial governance in legislation, institusional system and improvement of human resources quality (Suhardjanto and Yulianingtyas, 2011). The Result of general audit concluded that the implementation of the activity has not been effective. In more detail, The Audit Board of The Republic of Indonesia reveals 70 findings containing 81 problems, 76 ineffectiveness problems valued Rp36,21 billion and 5 issues of loss valued at Rp7,47 billion (IHPS I, 2016).

In IHPS I 2016 found that the problem of potential state losses generally occurs because the officials are negligent from their responsibility and not obeying thoroughly and understanding the applicable provision, policies/guidlines / SOP have not been set and have not implemented optimally the competence and responsibility in managing state property and weak supervision.

\section{THEORETICAL BASIS}

\section{Agency Theory}

Agency problems appear when the principal delegates decision-making authority to the agent. This agency relationship raises the problem, namely the existence of asymmetric information, where one party has more information than the other party. Agency problems occur in all organizations. At the firm, agency problems occur between the shareholders as principal and management as agents. In the government sector, agency problems occur between officials elected government as principals and voters (community) as agents (Zimmerman, 1977).

theory the local government management should be supervised to ensure that the management is carried out in full compliance with the various applicable laws and regulations. According to Law No. 15 of 2004, The audit is the process of identification problem, analysis and evaluation independently, objectively, and profesionally base on The Audit
Standard of Indonesia, to assess the accuracy, precison, credibility, and information reliability about state financial governance. By enhancing the local government accountability, the society will receive the information of the local administration in the region will be sufficient, and the information asymmetry will be decreased between the society and the government (Sudarsana and Rahardjo, 2013).

\section{Contingency Teory}

The development of contingency theory began when Burn and Stalker (1961) conducted a study of 20 industrial organizations in England and Scotland, to see how the effect of environmental change on managers and on the organization. Then Burn and Stalker distinguish that the organizations they studied can be distinguished into two different types of structures, namely mechanistic and organic structure (Kusdi, 2009: 73)

This theory is called contingency because Burn and Stalker conclude that the effectiveness of each type of organizational structure is «contingent» on the type of environment encountered. According to them, mechanistic organizations are effective if the environment is stable and tasks can be handled with routine mechanisms. As for the environment that tends to change and the nature of the problem can not be overcome in routine ways, organic organizations will be more supportive (Kusdi, 2009).

\section{Expectancy Theory}

Halim and Syam (2014: 161) wrote the expectancy theory by considering that motivation has three elements, namely as follows:

1. Expectancy is relationship between effort and performance, adding the efforts will improve theperformance (element expectancy).

2. The perseption of relationship between performance and outcome is a good performance will result reward.

3. The reward is attractive 
The performance of Local Government Administration

Bastian (2006: 274) stated that performance is the administration achievement from an activity/ program/policy to realize target, aim, mission and vision of an organization. Performance is an organization achievement in certain period of time.

Base on the Law No. 3 2007, The Report of Local Government Administration is Administration report of local government in one budgeting period base on Local Development Work Plan that have been set by the local government to central government. The Report of Local Government Administration is used as a basis to evaluate the local government administration and as a further coaching material in accordance with the law.

Refer to PP No 6, 2008 stated that The Local Government Administration Performance Evaluation is a collection and systematic data analysis toward the local government administration by using performance measurement system. The Local Government Administration Performance Evaluation is prepared to assess the performance of local government administration in an attempt to performance improvement base on good governance.

Here is the following intent and purpose The Local Government Administration Performance Evaluation base on http://otda.kemendagri.go.id/:

1. To find out the local government administration achievement in utilizing local potency by assessing the outcome achievement and achievement of the target;

2. To compare the performance achievement between regions in all province in Indonesia;

3. As feedback recommendation for the local government to improve the performance of the local government administration;

4. As basis for the central government to give reward to local government that have the best performance from The Local Government Administration Performance Evaluation toward The Report of Local Government Administration;
5. As basis the central government for coordination in improving region capacity, refer to Perpres No. 59, 2012 about National Framework to Local Government Capacity Improvement.

\section{Regional Wealth Level}

Wealth is a resource be in the form of assets. The Definition of Asset in accounting perspective is assets owned by the company in the form of tangible and intangible assets and consist of some particular account. Assets is wealth in the form of all account such as account receivable, prepaid rent, investment etc. Asset is wealth owned by the entity that measurable by using monetary unit and sorted by the liquidity level to cash (Warren et al., 2014).

Local Government that own more asset should be more flexible in utilizing the local potency to spend it in region expenditure in effort to improve service to society so that the performance become better like expected (Mustikarini and Fitriasari, 2012).

\section{Dependency Level of Central Government}

Base on Law No 33, 2004 about Financial Balance between Central government and Local Government "General allocation fund from National Budget Revenue allocated to local government for funding the region need in term of decentralization." General allocation fund used for funding local government administration so that capable realize society service. The supervision from the central government is set to motivate local government to perform even better. If the dependency level is higher to central government so the local government service to society will be better so the performance will be better (Mustikarini and Fitriasari, 2012).

General allocation fund given by central government to fund the deficit from the local government in utilizing locally generated revenue. General allocation fund is Block Grant which is the using of General allocation fund given to local government corresponding to priority, activity and local need on purposed to improve the public service in order to realize local autonomy (Renas and Muid, 2014). 


\section{Capital Expenditure Contribution}

Base on law No 23, 2014 article 298 (1), local expenditure mainly focused on funding mandatory activity related to basic service that prepared with minimum service standard. If more spending by the local government can make the local government easier in realizing the development program that have been set in the region. The efficient and appropriate of local expenditure management will improve the local government financial performance (Noviyanti and Kiswanto, 2016).

Base on Peraturan Pemerintah RI No. 71 (2010), the expenditure classification base on economy was in following explanation:

1. Operational Expenditure is the budget for daily expenditure of local/central government that give short term benefit. Operational Expenditure can be Personnel Expenditure, Good Expenditure, Interest Expenditure, subsidy, grant, social grants.

2. Capital Expenditure is a budget for get fixed asset and other asset that give benefit more that one accounting period. Capital Expenditure can be all expenditure to get Land, Building,
Equipment and Other Intangible Asset.

3. Other expenditure is a budget to unusual activity and unexpexted to spend again such as fund for disaster relief, social disaster, and other unexpected expenditure that really needed in the local/central government administration.

\section{Legislature Size}

In Indonesia government, the legislation board is Regional People's Representative Assembly. Regional People's Representative Assembly has legislative function, budgetary and controlling. In terms of that function, Regional People's Representative Assembly has dutie, authorities, right and obligation both individually and institutionally (Wikipedia.Org; 2017).

According to Setyaningrum and syafitri (2012), Regional People's Representative Assembly as the people's representative has controlling function, which is controlling the government administration so that the policy will fight for people's aspirations and supervise the implementation and reporting of local government financial information so that will create the accountable and transparent situation in

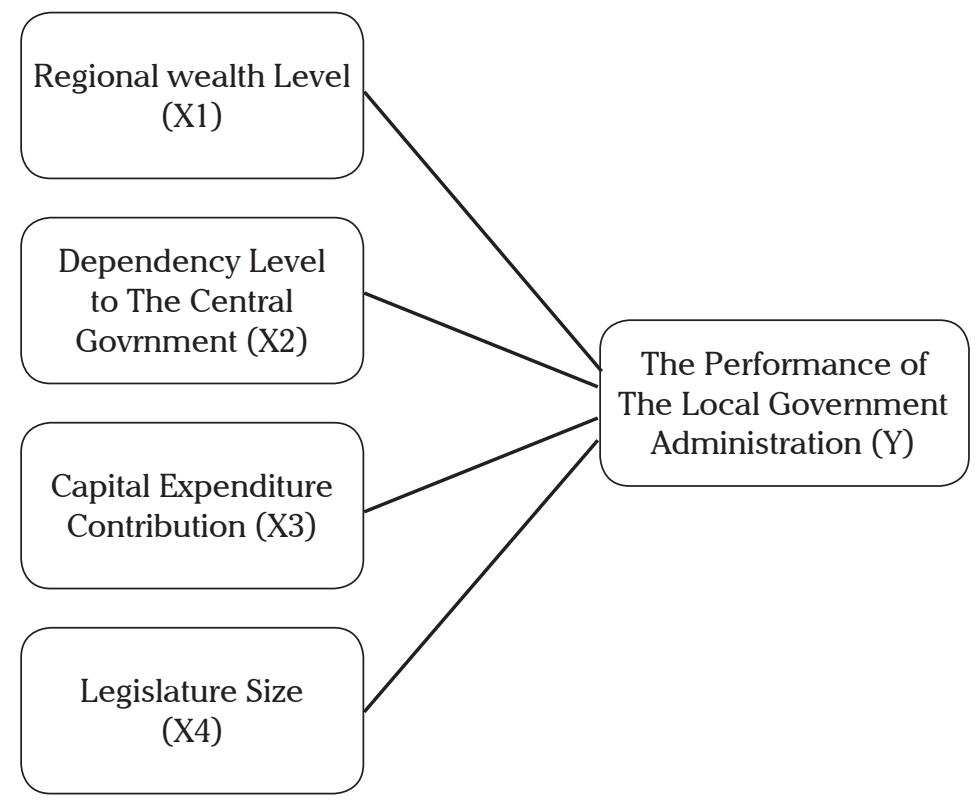

Picture1. Research Framework 
the local government. The controlling among the logal governance management by the legislative board to executive board is very important, because the controlling is one of the efforts to guarantee the implementation policies in local government and central government goes well (Winarna and Murni, 2007).

\section{Research Hyphotheses Development}

The Effect of Regional Wealth Level to The Performance of Local Government Administration There are different result about the effect of the Regional Wealth Level to The Performance of Local Government Administration. Mustikarini and Fitriasari (2012) and Sudarsana and Rahardjo (2013) shown that The Regional Wealth Level had a positive signficant to the performace of local government. But different result in Kusumawardani (2012), Noviyanti and Kiswanto (2016) shown that The Regional Wealth Level had insignificant Effect to The Performance of Local Government.

The research of Mustikarini and Fitriasari (2012) found that the Regional Wealth Level also had positive significant effect on regional performance score. When region with big asset will be expected to perform better in manage the asset for society service. The result of this study in line with Laswad et al. (2005) which found significant effect between Local Authority wealth in the City with the voluntary disclosure of internet financial reporting.

Base on that explaination, The first hyphotheses is proposed to be:

H1: The Regional Wealth Level Had Positive Significant Effect on The Local Government Administration

The Effect of The Dependency Level to The Central Government to The Performance of Local Governance Administration

There are different results about the effect of The Dependency Level to The Central Government to The Performance of Local Government. Marfiana and Kurniasih (2013) and Noviyanti and Kiswanto (2016) found that dependency level to the central government had positive significant effect to the performance of local government. While Setyaningrum and Syafitri (2012) and Sudarsana and Rahardjo (2013) found that dependency level to the central government had no significant effect to the performance of the local government.

Dependency level to the central government had effect to the performance of the local government administration, because if the the general allocation fund is allocated increase, the central governmen will supervise the local government even tighter in general allocation fund administration compare to the local government who get less general allocation fund. So, it motivated local government to perform even better because the supervision from central government become greater. Because of that, more general allocation fund from central government it was expected that the public service to the society woukd be better (Sudarsana and Rahardjo, 2013)

Based on the explanation, the second hypotheses was puposed:

H2: Dependency Level to The Central Government had Positive Significant to the Performance of The Local Governmnent Administration.

\section{The effect of Capital Expenditure to The Performance of The Local Government Administration}

The different result shown about the effect of the capital expenditure effect to the performance of the local government administration. Noviyanti and Kiswanto (2016) found that the local government expenditure expenditure had positive significant to the performance of the local government. This result supported the result of Sjoberg (2003) that shown there is a positive relation between government expenditure for consumption and investment and macro economic performance in Sweden in 19602001. While according to Sudarsana and Rahardjo 
(2013) and Renas and Muid (2014) found that region expenditure had no significant effect to the performance of the local government.

Noviyanti and Kiswanto (2016) found that region expenditure had significant effect to the financial performance of the local government. If the expenditure of the local government increase it will cause the local government in realize the program of development in that region become easier. The result supported the result of Marfiana and Kurniasih (2013) found that local government expenditure had positive significant to the financial performance of the local government. This case indicate that local government capital expenditure had been realized to increase the performance of the local government in regional development. Beside that, the positive significant relation also found by Artha et al.(2015).

Base on the explanation, the third hypotheses will be purposed:

H3: The capital Expenditure Contribution Had Positive Significant to The Performance of The Local Government Administraton.

The Effect of Legislature Size to The Performance of The Local Government Administration

There were different result at some research about the effect about this variable, Gilligan and Matsusaka (2001) and Kusumawardani (2012) found that legislature size had positive significant effect to the local government performance. The other way, Setyaningrum and Syafitri (2012) and Sari (2016) found insignificant effect between the legislature size and the local government performance.

The result of Kusumawardani (2012) found that legislature size had significant effect to the financial performance of the local government. Legislature Size variable explain that the role and the function of legislative board supervision that run well can increase the financial performance of the local government. The pogram implementation in local government that well supervised will create good performance as well. This result supported the research of Gilligan and Matsusaka (2001).

Base on the explanations so the fourth hypotheses beed purpossed:

H4: The Legislature Size Had Positive Significant to The Performance of The Local Government Administration.

\section{METHODS}

This research used Purposice Sampling Method. The sample in this research consist of 293 LKPD province, region, city in 2015 in Indonesia that had been audited by The Audit Board of the Republic Indonesia. The Sampling Selection base on this criteria in table 1.

Tabel 1. The Result of Sample and Populaton Selection

\begin{tabular}{lr}
\hline \multicolumn{1}{c}{ Explanation } & Amount \\
\hline The Local government Financial Statement & 542 \\
\hline The Local goverment that did not got unqualified opinion & $(206)$ \\
\hline The Local government that did not prepared The complete data & $(4)$ \\
\hline The local government that did not publish the amount of legislature board & $(2)$ \\
\hline
\end{tabular}

The local government that did not shown in the rank of administration performace status 
Tabel 2. The variable Measurement

\begin{tabular}{clll}
\hline No & Code & \multicolumn{1}{c}{ Variable } & Measurement \\
\hline 1 & SC & $\begin{array}{l}\text { The Performance of Local Government } \\
\text { Administration }\end{array}$ & EKPPD \\
\hline 2 & LnTA & Local Wealth Level & Ln Total Asset \\
\hline 3 & DAU & $\begin{array}{l}\text { The Dependency Level to The Central } \\
\text { Government }\end{array}$ & $\frac{\text { General Allocation Fund }}{\text { Total Income }}$ \\
\hline 4 & BM & Capital Expenditure Contribution & $\frac{\text { Capital Expenditure Realization }}{\text { Total of Expenditure Realization }}$ \\
\hline 5 & LnDPRD & Legislature Size & Ln Amount of Local Legislature Board \\
\hline
\end{tabular}

\section{RESULTS AND DISCUSSION}

\section{Results}

Base on table 3, descriptive statictic from each variable can be eplained in following point:

1. The performance of the local government (SC) had maximum score 3,5472 which is the highest score of the local government administration in 2015 own by Sidoarjo region and the lowest score owned by Bekasi City with the score 0,130 . The average of the local government administration was 2,917 which meant as an average the performance of the local government administration was good because it is in the high achievement criteria. The Deviation Standard shown the score 0,4026 , it meant the data were heterogeneous.

2. The first Independent Variable, The Wealth Level Ln TA) is natural logarithm from total asset from each local government. The maximum and minmum score were 31,32750 and 27,02897 . The maimun score owned by Ma- rauke Region with the amount of total asset $\mathrm{Rp}$ 40.305.237.635.265 and the minimum score owned by Bolaang Mongondow Timur region with the amount of total asset Rp 547.684.911.742. The average score for this variable was 28,55763 equivalent to Rp 308.706.562.119.543 and Deviation Standard was 0,752010 .

3. The second independent variable, The dependency level of the central government have a maimum score 1,541253 and minimum score 0,000000 . The local government that had maimum score on this variable was Gorontalo Utara Region and the minimum one was Kutai Kartanegara region. The average score this variable was 0,475868 and deviation standard was 0,157674 .

4. The third independen variable, the capital expenditure contribution had maimum score 0,569035 and minimum scoe 0,000276. Local government that had maximum score was Teluk Bintuni Region and the logal government with minimum score was Donggala Region. The

Tabel 3. Descriptive Statistic

\begin{tabular}{lcccccc}
\hline \multicolumn{1}{c}{ Variable } & N & Mean & Median & Maximum & Minimum & Std. Dev. \\
\hline SC & 293 & 2,9175 & 2,9793 & 3,5472 & 0,1309 & 0,4026 \\
\hline Ln TA & 293 & 28,55763 & 28,40757 & 31,32750 & 27,02897 & 0,752010 \\
\hline DAU & 293 & 0,475868 & 0,505858 & 1,541253 & 0,000000 & 0,157674 \\
\hline BM & 293 & 0,259033 & 0,244318 & 0,569035 & 0,000276 & 0,088029 \\
\hline Ln DPRD & 293 & 3,572272 & 3,555348 & 4,605170 & 2,484907 & 0,338615 \\
\hline
\end{tabular}


average score on this variable was 0,259033 and deviation standard 0,088029. This case shown that capital expenditure had contribution to Total of Expenditure Realization only about $25 \%$, so there was $75 \%$ effect given by other element of local government ependiture.

5. Last Independent Variable, Legislature Size had maximum score 4,605170 and minimum score 2,484907. The local government that had maimum score was Jawa Barat Province, Central Java Province and East Java Province with the amount 100 Legislature Board Member and minimum score was Kepulauan Riau was about 12 legislature board member. The average score was 3,572272 and had deviation standard 0,338615 . This case shown that each 3,5722272 from legislature board from the total board from all local government had contribution to increase the performance of local government administration.

\section{Normality Test}

Residual was stated had normal distributin if the significant score of Jarque-Bera (JB) was higher than 5\% and had no normal distribution if the score of Jarque-Bera (JB) under than 5\%. Base on the statistically test, normality test of histogram shown that Jarque-Bera (JB) score was 2351,955 with p score was 0,000000 . Base on that residual score, the data had no normal distribution because the p scoe was under that 0,05 . According to Winarno (2011) stated that the multivariate analysis, the researcher used the guidance if the variable consisted of 30 data, so the data had been believed that the data had normal distribution.

\section{Multicolinearity Test}

Menurut Ghozali (2013), if the corelation among variabel not upper that 0,09 , so we can said that had no multicolinearity among independent variables. The output of correlation matrix on this research shown no multicolinearity indication among variables. This case shown from correlation score among variables lower than 0,90 .

\section{Heteroscedasticity Test}

This research used White Test to detect the existence of heteroscedasticity indication. The Output of White test shown that Obs*R-squared score had probability chi-square insignificant or more than 0,05 (score $p=0,8379$ ). Because of that result, the data can be stated that the result of white test shown that no heteroscedasticity in regression model.

\section{Autocorrelation Test}

The autocorrelation test D-W shown that the score was 1,676718 at Durbin-Watson, so the data can be stated statistically no autocorrelation in regression model. This case caused if $d$ was between 1,54 and 2,46 , so the data had no autocorrelation indication. And if $\mathrm{d}$ was between 0 until 1,10, the data had positive autocorrelation, and so on.

Tabel 4. OLS Regression Result

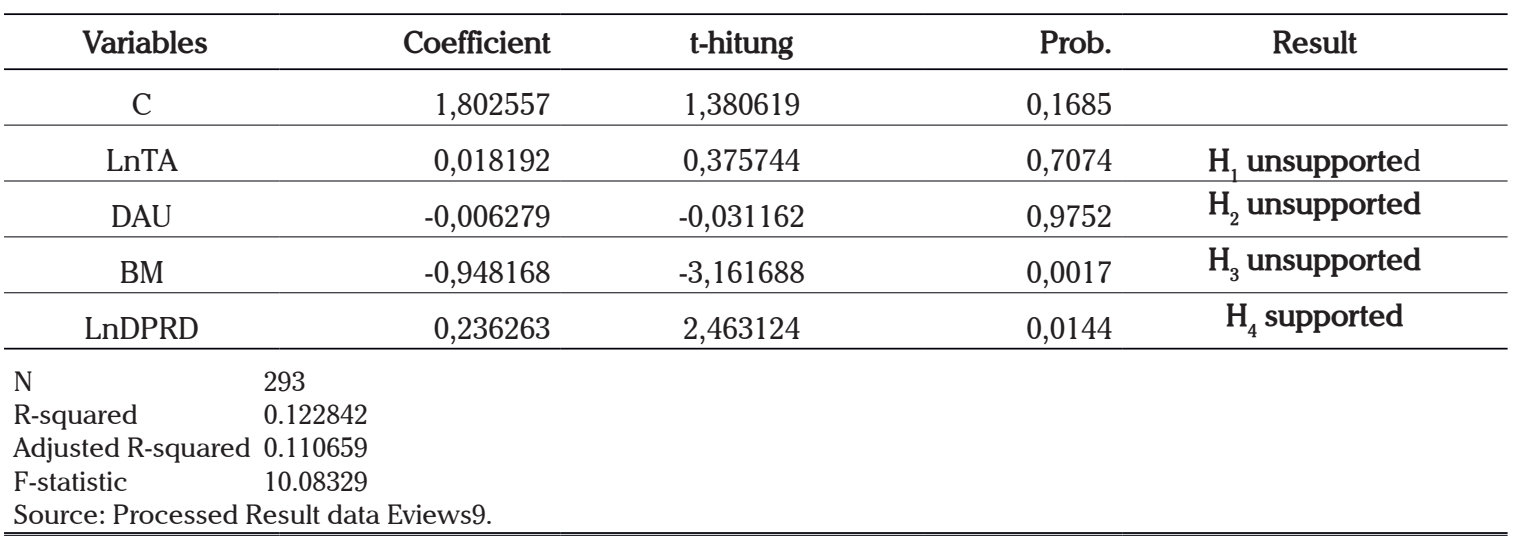


Hypotheses Test

Regression Model Test

Base on the result of OLS Regresion on the table four, so the model can be set to be:

$\mathrm{SC}=1,802557+0,018192 \mathrm{LnTA}-0,006279 \mathrm{DAU}-$ 0,948168 BM + 0,236263 Ln DPRD

\section{Discussion}

1. The Effect of The Regional Wealth Level to The Performance of The Local Government Administration

The result of OLS Regression shown that the regional wealth level had insignificant effect to the performance of the local government administration. This case can be seen from the regression coefficient of regional wealth level was 0,018192 with significant score 0,7074. Because the significant score more that 0,05 , so the first hypotheses of this study unsupported. Which mean, no significant effect between regional wealth level to the performance of local government admnistration. This result didn't support the previous hypotheses that the regional wealth level had positive significant effect to the performance of the local government administration. The result indicated that the role of the regional wealth level in increasing the performance of the local government admnistration did not run like what expected. (Noviyanti and Kiswanto, 2016). This result supported with the result of previous study,Marfiana and Kurniasih (2013), Noviyanti and Kiswanto (2016), Gamayuni (2016), and Kusuma (2017).

2. The Effect of Dependency to the Central Government to The Performance of The Loca Government Administration

This study shown that the dependency level to the central government had insignificant effect to the performance of the local government administration. The regression coefficient of dependency level to the central government was $-0,006279$ and the significant score
0,9752 . Becausse the significant score more than alpha $=0,05$, so the second hypotheses on this study unsupported. This result did not support the hypotheses that the dependency level to the central government had positive significant effect to the performance of the local government administration. This case shown that there was a possibility the central government nowadays lack of supervision to the general allocation fund that delivered to the local government. This result supported the previous study Setyaningrum and Syafitri (2012) but different with the result of Noviyanti and Kiswanto (2016).

3. The Effect of Capital Expenditure Contribution to The Performance of The Local Government Administration.

This study shown that capital expenditure contribution had negative significant to the performance of the local government administration. The Regression coeffiient of the capital expenditure was - 0,948168 and the significant score 0,0017 . Although the significant score less than 0,05 for the third hypotheses was unsupported, because the coefficient regression had negative score. Because of that the result didn't support hypotheses that the capital expenditure contribution had positive significant effect to the performance of the local government administration. This case indicate that the local government budgetting and planning system was still weak (Nurdin, 2014). The result different with the result of Sjoberg (2003) but supported the result study of Sudarsana and Rahardjo (2013) and Nurdin (2014). other indication that there was an asymmetric information between agent (government) who had direct access to the capital expenditure with principal (Society). Because of this asymmetric information make a possibility of deviation or corruption by agent. Besaide that, because of that big capital expenditure, one region can not perform efficienly in managing the finance (Sudarsana and Rahardjo, 2013). 
4. The Effect of Ligislature Size to The Performance of The Local Government Administration

This study shown that legislature had positive significant effect to the performance of the local government administration. Legislature size had regression coefficient score was 0,236263 with significant score 0,0144 . Because of significant score less than alpha $=0,05$ so the fourth hypotheses on this study was supported. This result supported the hypotheses that legislature size had positive significant effect to the performance of the local government administration. This indicated that if the role and the function of the supervision from legislature board can increase the performance of the local government administration. The result supported the previous study such as Gilligan and Matsusaka (2001), Kusumawardani (2012), and Setyaningrum and Syafitri (2012). According to Kusumawardani (2012), Legislature board as society representative (principal) need to control the administration of local government program (agent) to make it in line with society aspiration. Which mean the role and the function of supervision from legislature board if it run well, it can increase the performance of the local government administration.

\section{MANAGERIAL IMPLICATION}

Although the performance score of the provincial, regency and municipal administration is of high value, the effect on the independent variables studied does not produce much significance. We find that in the EKPPD method there is still less objectivity. Especially in calculating and assessing the composite index of the two main variables, namely the Performance Achievement Index and the Material Conformity Index, the calculation and assessment of the composite index still needs to be improved so that the EKPPD results can be of higher quality.

\section{CONCLUSION}

On this study the, the aim wa to examine the effect of regional wealth level, Pada penelitian ini menguji pengaruh tingkat kekayaan daerah, dependency level to the central government, regional capital expenditure and legislture size to the performance of the local government administration in provinces, regions, and cities in Indonesia in 2015. This study used 293 samples of financial statement of provinces, regions, and cities in Indonesia in 2015. The average score of performance of the local government administration was 2,917 which mean the performance of the local government administration was good at the hugh achiement criteria.

The performance of the local government administration was processed with least squares method, from four independent variable were examined, there is only one variable that give positive significant effect to the performance of the local government administration. The variable that had positive significant effect was legislature size $\left(\mathrm{X}_{4}\right)$. While the regional wealth level $\left(\mathrm{X}_{1}\right)$ had insignificant effect to the performance of the local government administration, but the coefficient score was positive. The dependency to the central government $\left(\mathrm{X}_{2}\right)$ had insignificant effect to the performance of the local government administration and the coefficient score was negative. The capital expenditure contribution $\left(\mathrm{X}_{3}\right)$ had significant effect to the performnce of the local government administration but the coefficient score was negative.

\section{Limitation}

This study had several limitation that need improvement in the next studies. The limitations were:

1. This study used cross section data, so the study only given description on the certein time only. The using of panel data probably will given explanation from time to time af the performance of the local government administration and can be seen the trend from each local government so can given better conclusion.

2. Indenpendent variable that used in this study Variasi independen only explained $11,11 \%$ the dependent variable. Which mean $81,89 \%$ was explained by from another outside this study. 
This case indicated that there are still another factors that can explained the performance of the local government administration th

3. at outside fom this study.

4. There was one element of classis assumtion test which was normality test that the residual score data on this study was distributed ubnormal. This case can be ignored according Winarno (2011), the researcher used this guidance if the variable more than 30 data so the distrubution assumed already normal. But the exact amount of observation probably able to minimalize that problem.

\section{Future research}

the suggestion for the next study were:

1. Used panel data so that can give description from time to time of the performance of the local government administration. Beside that can be seen the trend from each variables from each local government.

2. On the level of the regional wealth level can be suggested that used another proxy, such as asset management quality. It was because the proxy on this study was total asset that had insignificant result.

3. The next study could be suggested that used another variables such as the weakness of the local government controlling systems, The uncompliance of the local government to the regulation, and the reaction of audit finds according to the recommendation from The Audit Boards of the Republic Indonesia.

\section{REFEREN CES}

Artha, R. D., Basuki, P., \& Alamsyah, M. (2015). Pengaruh Karakteristik Pemerintah Daerah dan Temuan Audit BPK Terhadap Kinerja Penyelenggaraan Pemerintahan Daerah (Studi Empiris Pada Pemerintah Kabupaten/Kota Di Provinsi NTB). Jurnal InFestasi, 11(2), 214-229.

Bastian, I. (2006). Akuntansi Sektor Publik: Suatu Pengantar. Jakarta. Penerbit Erlangga.

Gamayuni, R. R. (2016). The Effect of Local Government Characteristics and the Examination Result of Indonesian Supreme Audit Institution on Economic Growth, with Financial Performance as Intervening Variable in District and City Government of Lampung Province. Research Journal of Finance and Accounting, 7(18), 75-81.

Gilligan, T. W., \& Matsusaka, J. G. (2001). Fiscal Policy, Legislature Size, and Political Parties: Evidence from State and Local Governments in the First Half of the 20th Century. National Tax Journal, 54(1), 57-82.

Godfrey, Jayne et al. (2010). Accounting Theory 7th Edition. Jakarta: John Wiley \& Son, Inc.

Halim, A. \& Kusufi, M. S. (2014). Akuntansi Sektor Publik. Edisi 2. Jakarta: Salemba Empat

Ikhtisar Hasil Pemeriksaan Semester (IHPS) I Tahun 2016. Jakarta: Badan Pemeriksaan Keuangan Republik Indonesia (BPK RI).

Kusdi. (2009). Teori Organisasi dan Administrasi. Salemba Humanika: Jakarta

Kusumawardani, M. (2012). Pengaruh Size, Kemakmuran, Ukuran Legislatif, Leverage Terhadap Kinerja Keuangan Pemerintah Daerah Di Indonesia. Accounting Analysis Journal, 1(1), 27-35.

Laswad, F., Fisher, R., \& Oyelere, P. (2005). Determinant of Voluntary Internet Financial Reporting by Local Government Authorities. Journal of Accounting and Public Policy, 24, 101-121. 
Marfiana, N., \& Kurniasih, L. (2013). Pengaruh Karakteristik Pemerintah Daerah dan Hasil Pemeriksaan Audit BPK Terhadap Kinerja Keuangan Pemerintah Daerah Kabupaten / Kota. Journal \& Proceeding Universitas Jenderal Soedirman, 3(1), $1-16$.

Mustikarini, W. A., \& Debby, F. (2012). Pengaruh Karakteristik Pemerintah Daerah dan Temuan Audit BPK Terhadap Kinerja Pemerintah Daerah Kabupaten/Kota di Indonesia Tahun Anggaran 2007. Forum: Simposium Nasional Akuntansi, 15.

Noviyanti, N. A., \& Kiswanto. (2016). Pengaruh Karakteristik Pemrintah Daerah Temuan Audit BPK Terhadap Kinerja Keuangan Pemerintah Daerah. Accounting Analysis Journal, 5(1), 1-10.

Peraturan Pemerintah Nomor 3 Tahun 2007 tentang Laporan Penyelenggaraan Pemerintahan Daerah Kepada Pemerintah, Laporan Keterangan Pertanggungjawaban Kepala Daerah Kepada DPRD, dan Informasi Laopran Penyelenggaraan Pemerintahan Daerah Kepada Masyarakat.

Peraturan Pemerintah Nomor 6 Tahun 2008 Tentang Pedoman Evaluasi Penyelenggaraan Pemerintahan Daerah.

Peraturan Pemerintah RI No. 71 Tahun 2010 Tentang Standar Akuntansi Pemerintahan

Renas, \& Muid, D. (2014). Pengaruh karakteristik Pemda dan Temuan Audit BPK terhadap Kinerja Pemda Studi pada Pemerintah Kabupaten/Kota di Propinsi Jawa Tengah Periode 2009-2011. Diponegoro Journal of Accounting, 4(3), 1-15.

Sari, I. P. (2016). Pengaruh Ukuran Pemerintah Daerah, Pad, Leverage, Dana Perimbangan dan Ukuran Legislatif Terhadap Kinerja Keuangan Pemerintah Daerah. JOM Fekon, 3(1), 679-692.

Sjoberg, P. (2003). Government Expenditure Effect on Economic Growth: The Case of Sweden 1960-2001. Bachelor's Thesis.

Sudarsana, H. S., \& Rahardjo, S. N. (2013). Pengaruh karakteristik Pemda dan Temuan Audit BPK terhadap Kinerja Pemda (Studi pada Pemerintah Kabupaten/Kota di Indonesia). Diponegoro Journal of Accounting, 2(4), 1-13.

Suhardjanto, D., \& Yulianingtyas, R. R. (2011). Pengaruh Karakteristik Pemerintah Daerah Terhadap Kepatuhan Pengungkapan Wajib Dalam Laporan Keuangan Pemerintah Daerah (Studi Empiris Pada Kabupaten/Kota Di Indonesia). Jurnal Akuntansi \& Auditing, 8(1), 30-42.

Setyaningrum, D., \& Syafitri, F. (2012). Analisis Pengaruh Karakteristik Pemerintah Daerah Terhadap Tingkat Pengungkapan Laporan Keuangan. Jurnal Akuntansi dan Keuangan Indonesia, 9(2), 154-170.

Undang-Undang Republik Indonesia Nomor 23 Tahun 2014 Tentang Pemerintahan Daerah.

Warren, C. S., Reeve, J. M., \& Fess, P. E. (2006). Pengantar Akuntansi Edisi 21, Buku I. Jakarta: Salemba Empat, 2 Jil., $21 x 26$ $\mathrm{cm}, 656$ hal.

Winarna, J., \& Murni, S. (2007). Pengaruh Personal Background, Political Background dan Pengetahuan Dewan Tentang Anggaran Terhadap Peran DPRD dalam Pengawasan Keuangan Daerah. Simposium Nasional Akuntansi, 10, 1-22.

Winarno, W. W. (2011). Analisis Ekonometrika dan Statistika dengan Eviews, Edisi Ketiga. Yogyakarta : Unit Penerbit dan Percetakan (UPP STIM YKPN).

Zimmerman, J. L. (1977). The Municipal Accounting Maze: An Analysis of Political Incentives. Journal of Accounting Research, $15,107-144$

https://id.wikipedia.org/wiki/Dewan_Perwakilan_Rakyat_Daerah/ diakses pada 4 September 2017, Pukul: 11.27 WIB, Lampung.

http://otda.kemendagri.go.id/FormMenu/DaftarEKPPD diakses pada 20 Oktober 2017, Pukul: 9.38 WIB, Lampung. 